\title{
Role of Procalcitonin and C-reactive Protein as Marker of Sepsis in Major Burn Patients: A Systematic Review and Meta-analysis
}

\author{
A. A. I. Yulan Permatasari ${ }^{1 *}$, I. G. P. Hendra Sanjaya ${ }^{1}$ D, I. Gde Raka Widiana ${ }^{2}$, I. Wayan Niryana ${ }^{3}$, A. A. G. N. Asmarajaya ${ }^{1}$, \\ Agus Roy R. H. Hamid", M. Suka Adnyana \\ ${ }^{1}$ Plastic Reconstructive and Aesthetic Surgery Division, Department of General Surgery, Faculty of Medicine Udayana \\ University, Sanglah General Hospital, Bali, Indonesia; ${ }^{2}$ Kidney and Hypertension Division, Department of Internal Medicine, \\ Faculty of Medicine Udayana University, Sanglah General Hospital, Bali, Indonesia; ${ }^{3}$ Neuro Surgery Division, Department of \\ General Surgery, Faculty of Medicine Udayana University, Sanglah General Hospital, Bali, Indonesia
}

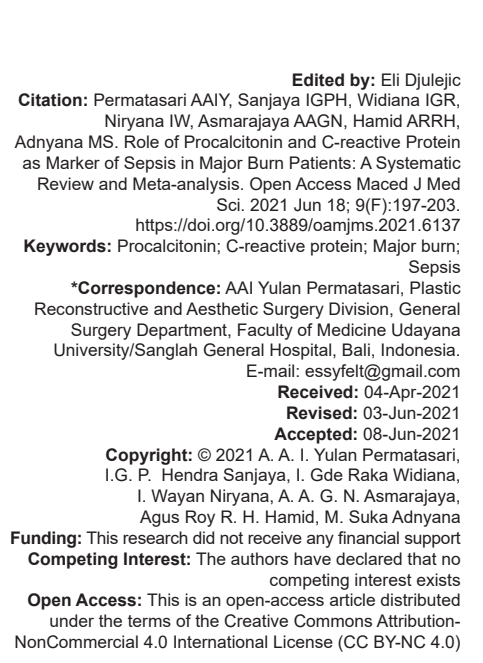

Abstract

AIM: Although absolute values for C-reactive protein (CRP) and procalcitonin (PCT) are well known to predict sepsis, it remains unclear how their diagnostic value in major burn patients as metabolic changes in bun
and symptoms for sepsis. This paper attempts to clarify these points for both of the markers.

METHODS: A comprehensive literature search of PubMed, Scopus, DOAJ, Web of Science, and the Cochrane Library databases for studies published up to June 1,2020, that evaluated PCT and/or CRP as a marker for diagnosing sepsis in burn patients was conducted. Review Manager 5.3 was used to analyze the data.

RESULTS: A total of 11 literatures were obtained. The combined sensitivity and specificity for PCT as assessed by meta-analysis were $88 \%$ and $89 \%$, respectively. The combined sensitivity and specificity of CRP were described as $85.5 \%$ and $57.5 \%$, respectively. Meta-analysis cannot be performed for CRP parameters because there are only two literatures that include CRP diagnostic test values.

DISCUSSION: PCT and CRP have additional diagnostic value for sepsis in patients with major burns. The pooled sensitivity and specificity of PCT are excellent. Although the difference in sensitivity between PCT and CRP is not very large, there are distinct differences in specificity. A low CRP specificity value will show many "false positives" when CRP is used as a biomarker.

CONCLUSION: PCT provides a better diagnostic value than CRP in cases of sepsis in major burn patients. More study on combination of biomarker, clinical presentation, and microbial culture for diagnosing sepsis are needed. Further large-scale research with cohort or case control design should be done.

\section{Introduction}

Sepsis in burns worsens the patient's prognosis and increases the risk of organ failure and death. The leading cause of death in burn patients is multiple organ dysfunction syndrome (MODS), which is a direct response to sepsis [1]. Identifying early sepsis is very important, given that every $6 \mathrm{~h}$ delay in the diagnosis of sepsis reduces survival by $10 \%$ [2]. Difficulty in diagnosing sepsis in burn is due to the systemic response to the burn itself clinically mimics sepsis [3], [4], [5].

Blood culture is the gold standard to identify sepsis, but it takes $48-72 \mathrm{~h}$ and cannot rapidly diagnose sepsis. The use of high-dose antibiotics in early stage also results in a very low detection rate for positive blood cultures, which will delay the diagnosis. Blood culture is also susceptible to external bacterial contamination, which can lead to misdiagnosis [4], [6]. It is presumed that various sepsis biomarkers originating from the host response to inflammatory stimuli could diagnose sepsis as early as possible so that sepsis treatment can be started early.

Studies in the past stated procalcitonin (PCT) and C-reactive protein (CRP) as superior biomarkers and play an important role in the occurrence of sepsis in burn patients. However, these studies still show inconsistent results. A study by Lavrentieva stated that PCT is useful as an early indicator of sepsis in severe burn patients [7]. Meanwhile, other study showed that PCT serum is not superior compare to CRP or blood leukocytes as a marker of sepsis in burn patients [8].

PCT is a calcitonin pro-hormone that is usually produced in the C-cells of the thyroid gland. In healthy humans, all PCT are broken down to calcitonin and only $<0.1 \mathrm{ng} / \mathrm{ml}$ is measured in the blood. PCT regulation will change during infection. There will be a massive release of PCT into the bloodstream depending on the severity of sepsis [9]. Serum PCT levels rise as early as $3 \mathrm{~h}$ after bacterial infection, reaching a peak around $20 \mathrm{~h}$. Higher levels of PCT are associated with the severity of sepsis [5]. 
CRP is an acute-phase protein and is released from the liver after stimulation of interleukin (IL-6) and other cytokines. CRP is a response to tissue damage and inflammatory or infectious processes [10]. CRP measurements are readily available, but elevated CRP levels are said to be nonspecific, as they can be observed right after surgery or trauma. High CRP levels correlate with disease severity and may reflect the effectiveness of antimicrobial therapy. Significantly elevated serum CRP levels predict the incidence of infection approximately 2-3 days before sepsis occurs [2].

This study analyzes the role of PCT and CRP as biomarkers to diagnose sepsis in patients with major burns since the use of PCT and CRP is not yet a standard and still a controversial. Researchers conducting a study in the form of a systematic literature review and meta-analysis. This study summarized the results of previous studies examining the relationship of PCT and CRP with the occurrence of sepsis in burn patients. This study also identified supporting evidence for the use of PCT and CRP as diagnostic markers for early detection of sepsis in patients with major burns.

\section{Methods}

\section{Literatures search strategy}

Researchers follow protocol from the Joanna Briggs (JBI) Institute for the systematic review of studies of diagnostic test accuracy [11]. Systematic review was performed by PubMed, Scopus, DOAJ, Web of Science, and Cochrane Library up to June 2020. The combined search term used was ([PCT OR PCT] AND [sepsis OR septic] AND burn patient) and ([CRP OR CRP] AND [sepsis OR septic] AND burn patient).

PCT defined as one of the biomarkers which correlates with the progression and severity of microbial invasion [5]. CRP is an acute-phase protein that increases in concentration under certain conditions such as inflammatory reactions or tissue damage caused by infectious or non-infectious diseases [2]. Both PCT and CRP are measured by taking a sample of the patient's venous blood and asses using various analyzer. Sepsis is a clinical suspicion of infection [1], [3]. It can be diagnosed through clinical judgment by experts, sequential organ failure assessment score, or American Burn Association (ABA) guideline. Burn patients defined as patient with burn injuries $\geq 20 \%$ total body surface area (TBSA). The burn area assesses clinically by expert [1].

\section{Selection of studies}

Studies included in our analysis if they met the following criteria: (i) The design was diagnostic test study with minimum sample of 10 , (ii) the study included adult mayor burn patients whom burned $\geq 20 \%$ TBSA, and (iii) the study was written in English. The studies were excluded for full text review if they were performed in children, geriatric, or subjects with comorbidities. Nonrelevant literature such as article review, non-experimental study, and meta-analysis were excluded from the study. To assure the quality of included studies and exclude the poorly designed or executed studies, the JBI Critical Appraisal Checklist for Diagnostic Test Accuracy Studies were performed [12]. Each literature was reviewed by two reviewers individually and assessed for quality appraisal.

\section{Data extraction}

Data were extracted from each included study using a structural data collection sheet to include the following items: Publication details, country of origin, design, setting, sample numbers, sample characteristic, PCT and CRP test and algorithm, and outcomes.

\section{Quality assessment}

Critical appraisal was performed as quality assessment. It was performed based on JBI Critical Appraisal Checklist for Diagnostic Test Accuracy Studies tool [12]. The tool included 10 items covering several dimension of study qualities. Each item was assessed by scoring "yes," "no," "unclear," or "not applicable." The score was the sum of the 10 items. "Yes" was accountable as 1 point, with maximum total score was 10 . To assure the quality of included studies, all of them should meet at least $50 \%$ of the 10 items.

\section{Statistical analysis}

We assessed heterogeneity between studies using the $I^{2}$ tests, represented the proportion of total variation in the estimated effect size due to heterogeneity rather than sampling error. When there was no significant heterogeneity between the studies ( $\left.p>0.1, l^{2} \leq 50 \%\right)$, we used fixed-effect meta-analysis. If there was statistical heterogeneity between the studies, the meta-analysis was performed using the random effects model ( $p \leq 0.1$, $\left.I^{2}>50 \%\right)$. We calculated pooled sensitivity and specificity and $95 \%$ confidence intervals $(\mathrm{Cl})$ for both PCT and CRP.

\section{Results}

\section{Study selection and quality assessment}

Our literature search identified 86 studies for full text review. By reviewing the literature full text, 36 studies were excluded due to not provide sufficient data, 6 articles were published in other language than English, 27 studies were not included adult burn patients as 
sample, and 6 studies were not categorized the outcome as sepsis or non-sepsis. By using this searching, it left 11 studies fulfilling the eligible criteria. The mechanism of journal search strategy is shown in Figure 1.

The quality of the studies included in this metaanalysis based on the JBI Critical Appraisal Checklist for Diagnostic Test Accuracy Studies [12]. From a total of 11 studies conducted quality assessment, 10 studies were classified as having good quality and only 1 study was poor, namely, the publication of Barati et al.

\section{Study characteristic and data extraction}

The studies included in this systematic review and meta-analysis were 11 studies originating from various countries such as Iran, France, Turkey, Spain, Korea, Greece, Tunisia, Germany and South Africa. Related studies were published over a long span of years, 1998-2019. The study design was a diagnostic test with eight prospective observational studies and three retrospective observational studies. Of the total 821 samples included, 235 samples (28.6\%) came from emergency room (ER), 257 samples (31.3\%) came from intensive care unit (ICU), and 329 samples $(40.1 \%)$ came from burn unit. The main characteristics of the studies are described in Table 1 and the results data for each study are presented in Table 2.

\section{Meta-analysis}

The analysis was carried out on seven studies presenting sensitivity and specificity of PCT levels. The

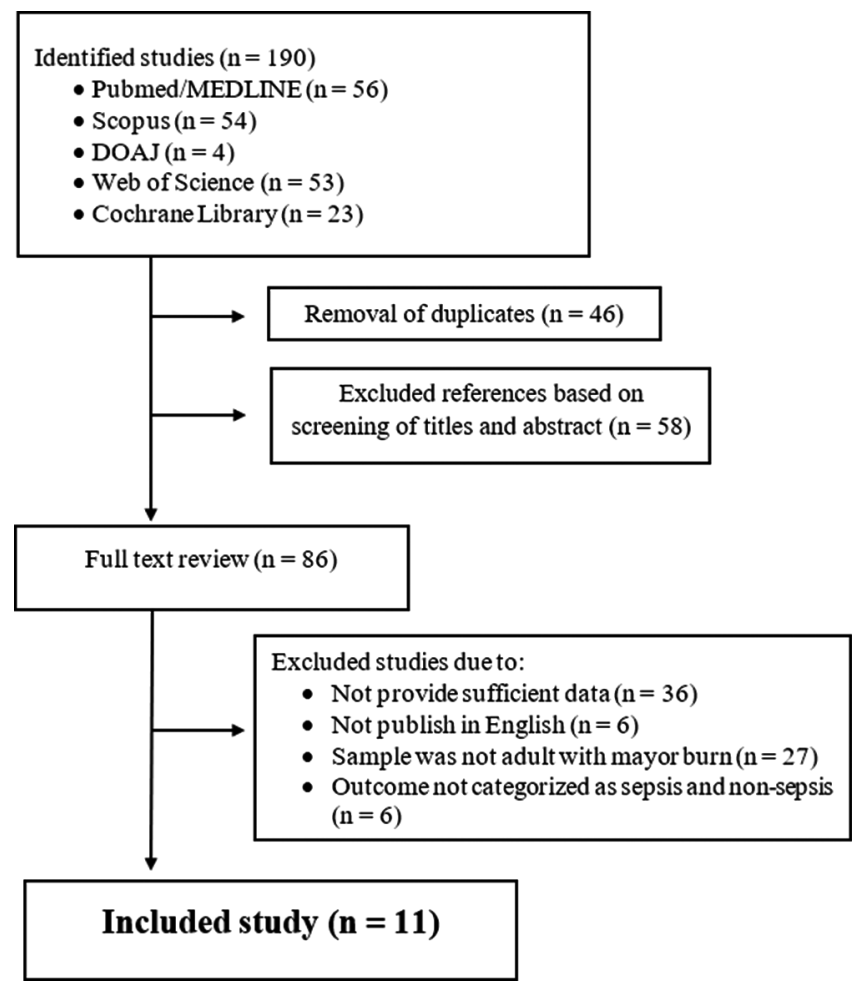

Figure 1: Flowchart of study screening and selection included in this study meta-analysis result of the sensitivity and specificity of PCT levels was shown on the forest plot in Figures 2 and 3, respectively. Based on the forest plot, $I^{2}=94.1 \%$, it showed the heterogeneity among studies. This heterogeneity might occur due to the small amount of literature included in the meta-analysis.

The value of pooled sensitivity was $88 \%(z=179.03 ; p=0.000)$ and specificity for PCT was $89 \%(z=66.06 ; p=0.000)$. The effect size was statistically significant since both sensitivity and specificity have $p<0.05$ and confident interval not across absolute value 1. Practically, PCT has high value of sensitivity and specificity, both are above $80 \%$.

Meta-analysis of the CRP sensitivity and specificity was not possible due to the limited literatures available. There were only two literatures presenting sensitivity and specificity of CRP. The data are presented in Figure 4. Roughly, it can be calculated that the combined sensitivity of the CRP was $5 \%$ and the specificity of combined CRP was $57.5 \%$. However, they were not statistically significance because of the variety between studies and the statistical combined effect could not be calculated.

\section{Discussion}

The sepsis-specific biomarkers able to detect host response and causative pathogens are useful in improving clinical management for septic patients [13], [14], [15]. The advantage of measuring these biomarkers in patients with suspected sepsis is reducing antibiotic use and associated side effects. This measurement can also assist to decide immediate treatment for sepsis. In addition, routine monitoring in critically ill patients also carries a minimal risk, providing the promising benefit of reducing patient mortality [1], [16]. The value of the diagnostic test has to be concerned because sepsis is one of the factors that increase the risk of mortality in burn patients.

Since our studies included studies originating from various countries and were published over a long span of years, 1998-2019, some laboratory procedures were not uniform. These techniques also could have been modified. The examination of PCT in the majority of studies used chemiluminescent method (PCT-Q) and immunoluminometric method, while the majority of CRP was examined using automated immunoturbidimetric assay method.

Sample size of individual study varied from 17 to 178 . This gives a different weighting from each study to the combined effect size. The smaller scale studies weigh less than larger ones in those pooled data. All the patients included were adult with burn area $\geq 20 \%$ TBSA. 
Table 1: Study characteristics included in this systematic review and meta-analysis

\begin{tabular}{|c|c|c|c|c|c|c|c|}
\hline Author, year & Study design & $\begin{array}{l}\text { Sample } \\
\text { size }\end{array}$ & $\begin{array}{l}\text { Mean age } \\
\text { (years) }\end{array}$ & $\begin{array}{l}\text { Mean burn } \\
\text { surface area }\end{array}$ & $\begin{array}{l}\text { Sepsis diagnostic } \\
\text { criteria }\end{array}$ & PCT value method & CRP value method \\
\hline Barati et al., 2008 & Prospective observational & 60 & $31.28 \pm 17.01$ & $62.31 \pm 20.57$ & ACCP/SCCM & PCT-Q & Bionic test kit \\
\hline Bargues et al., 2007 & Prospective observational & 25 & $40 \pm 14$ & $40 \pm 17$ & ACCP/SCCM & PCT-Q + PCT-LUMI & Agglutination test kit \\
\hline Cakir-Madenci et al., 2014 & Prospective observational & 37 & $40 \pm 17$ & $36.1 \pm 23.4$ & ABA & PCT-LUMI & Nephelometric \\
\hline $\begin{array}{l}\text { Egea-Guerrero et al., } \\
2015\end{array}$ & Prospective observational & 17 & $44.34 \pm 7.9$ & $47.43 \pm 22.9$ & ABA & ECLIA test & $\begin{array}{l}\text { Particle enhanced } \\
\text { immunoturbidimetric assay }\end{array}$ \\
\hline Kim et al., 2012 & Prospective observational & 175 & 45 & 40 & Clinical & $\begin{array}{l}\text { Automated } \\
\text { immunoanalyzer }\end{array}$ & N/A \\
\hline Lavrentieva et al, 2012 & Prospective observational & 145 & $48.2 \pm 18.3$ & $38.8 \pm 18$ & ABA & PCT-LUMI & $\begin{array}{l}\text { Automated } \\
\text { immunoturbidimetric }\end{array}$ \\
\hline Mokline et al., 2015 & Prospective observational & 121 & $37 \pm 17$ & $23 \pm 17$ & ACCP/SCCM & PCT-LUMI & $\mathrm{N} / \mathrm{A}$ \\
\hline Sachse et al., 1999 & Retrospective observational & 19 & 41 & 32 & Clinical & PCT-LUMI & $\begin{array}{l}\text { Vitros } 250 \text { Chemistry } \\
\text { analyzer }\end{array}$ \\
\hline Seoane et al., 2014 & Retrospective observational & 17 & $52.5 \pm 17.2$ & $37.6 \pm 22.9$ & ACCP/SCCM & ECLIA test & $\mathrm{N} / \mathrm{A}$ \\
\hline Von Heimburg et al., 1998 & Prospective observational & 27 & 37.3 & 51 & ABA & PCT-LUMI & $\begin{array}{l}\text { Automated } \\
\text { immunoturbidimetric }\end{array}$ \\
\hline Wineberg et al., 2019 & Retrospective observational & 178 & $39.7 \pm 14.7$ & 31.7 & ABA & N/A & $N / A$ \\
\hline
\end{tabular}

PCT-LUMI: Immunoluminometric method; ECLIA: Electrochemiluminescence immunoassay

Table 2: Extracted results from each studies

\begin{tabular}{|c|c|c|c|c|c|c|c|c|c|c|c|c|c|c|}
\hline \multirow[t]{2}{*}{ author, year } & \multicolumn{7}{|l|}{ Procalcitonin } & \multicolumn{7}{|l|}{ CRP } \\
\hline & $\begin{array}{l}\text { Sepsis (Mean } \pm \text { SD)/ } \\
\text { (Median (IQR) }\end{array}$ & $\begin{array}{l}\text { Non-sepsis } \\
\text { (Mean } \pm \\
\text { SD)/(Median } \\
(\mathrm{IQR})\end{array}$ & $p$ value & Sensitivity & Specificity & AUC & $\begin{array}{l}\text { Optimal } \\
\text { cutoff } \\
(\mathrm{ng} / \mathrm{ml})\end{array}$ & $\begin{array}{l}\text { Sepsis } \\
(\text { Mean } \pm \text { SD)/ } \\
\text { (Median } \\
(\text { IQR) }\end{array}$ & $\begin{array}{l}\text { Non-sepsis } \\
(\text { Mean } \pm \text { SD)l } \\
\text { (Median } \\
(\text { IQR) }\end{array}$ & $p$ value & Sensitivity & Specificity & AUC & $\begin{array}{l}\text { Optimal } \\
\text { cutoff } \\
\text { (mg/L) }\end{array}$ \\
\hline $\begin{array}{l}\text { Barati et al., } \\
2008\end{array}$ & $8.45 \pm 7.8 \mathrm{ng} / \mathrm{ml}$ & $0.5 \pm 1 \mathrm{ng} / \mathrm{ml}$ & $<0.001$ & $100 \%$ & $89.8 \%$ & 0.97 & 0.5 & $\begin{array}{l}2.8 \pm 2.3 \\
\mathrm{mg} / \mathrm{ml}\end{array}$ & $\begin{array}{l}2.5 \pm 1.4 \\
\mathrm{mg} / \mathrm{ml}\end{array}$ & 0.52 & $\mathrm{~N} / \mathrm{A}$ & $\mathrm{N} / \mathrm{A}$ & $\mathrm{N} / \mathrm{A}$ & $\mathrm{N} / \mathrm{A}$ \\
\hline $\begin{array}{l}\text { Bargues } \\
\text { et al., } 2007\end{array}$ & $1.751 \pm 1.19 \mathrm{ng} / \mathrm{ml}$ & $\begin{array}{l}0.288 \pm 0.01 \\
\mathrm{ng} / \mathrm{ml}\end{array}$ & & $42.4 \%$ & $88.8 \%$ & 0.655 & 0.534 & $\begin{array}{l}132.6 \pm 12.9 \\
\mathrm{mg} / \mathrm{L}\end{array}$ & $\begin{array}{l}18.5 \pm 6.3 \\
\mathrm{mg} / \mathrm{L}\end{array}$ & & $79.5 \%$ & $60.3 \%$ & 0.749 & 102 \\
\hline $\begin{array}{l}\text { Cakir- } \\
\text { Madenci } \\
\text { et al., } 2014\end{array}$ & $\begin{array}{l}2.04(0.206-87.4) \\
\mathrm{ng} / \mathrm{ml}\end{array}$ & $\begin{array}{l}0.293(0.034- \\
10.55) \mathrm{ng} / \mathrm{ml}\end{array}$ & 0.0012 & $75.7 \%$ & $78.6 \%$ & 0.847 & 0.759 & $\begin{array}{l}133(37-206) \\
\mathrm{mg} / \mathrm{L}\end{array}$ & $\begin{array}{l}52(3-204) \\
\mathrm{mg} / \mathrm{L}\end{array}$ & $<0.0001$ & $91.6 \%$ & $58.2 \%$ & 0.819 & 65 \\
\hline $\begin{array}{l}\text { Egea- } \\
\text { Guerrero } \\
\text { et al., } 2015\end{array}$ & $\begin{array}{l}1.89(1.19-5.35) \\
\mathrm{ng} / \mathrm{ml}\end{array}$ & $\begin{array}{l}0.81 \\
(0.35-1.95) \\
\mathrm{ng} / \mathrm{ml}\end{array}$ & $<0.001$ & $78 \%$ & $91.9 \%$ & 0.71 & $\mathrm{~N} / \mathrm{A}$ & $\begin{array}{l}274 \\
(222-365) \\
\mathrm{mg} / \mathrm{L}\end{array}$ & $\begin{array}{l}172.5 \\
(73.75- \\
290.75) \mathrm{mg} / \mathrm{L}\end{array}$ & $<0.001$ & $\mathrm{~N} / \mathrm{A}$ & $\mathrm{N} / \mathrm{A}$ & 0.72 & $\mathrm{~N} / \mathrm{A}$ \\
\hline $\begin{array}{l}\text { Kim et al., } \\
2012\end{array}$ & $\begin{array}{l}\text { Survived sepsis: } 0.57 \\
(<0.05-32.77) \mathrm{ng} / \mathrm{ml} \\
\text { Non-survived sepsis: } \\
5.26 \\
(<0.05-184.44) \mathrm{ng} / \mathrm{ml}\end{array}$ & $\begin{array}{l}0.06 \\
(<0.05-1.4) \\
\mathrm{ng} / \mathrm{ml}\end{array}$ & $<0.0001$ & $77.6 \%$ & $82.1 \%$ & 0.844 & 2 & $\mathrm{~N} / \mathrm{A}$ & N/A & $\mathrm{N} / \mathrm{A}$ & $\mathrm{N} / \mathrm{A}$ & $\mathrm{N} / \mathrm{A}$ & $\mathrm{N} / \mathrm{A}$ & N/A \\
\hline $\begin{array}{l}\text { Lavrentieva } \\
\text { et al, } 2012\end{array}$ & $23.9(1.6-34) \mathrm{ng} / \mathrm{ml}$ & $\begin{array}{l}5.6(0.4-8) \\
\mathrm{ng} / \mathrm{ml}\end{array}$ & 0.001 & $88-90.4 \%$ & $82.5-95.2 \%$ & 0.86 & 1.5 & $\begin{array}{l}17.65(2-39) \\
\mathrm{mg} / \mathrm{L}\end{array}$ & $\begin{array}{l}12.0 \\
(4.5-30,7) \\
\mathrm{mg} / \mathrm{L}\end{array}$ & $<0.001$ & $\mathrm{~N} / \mathrm{A}$ & $\mathrm{N} / \mathrm{A}$ & $\mathrm{N} / \mathrm{A}$ & N/A \\
\hline $\begin{array}{l}\text { Mokline } \\
\text { et al., } 2015\end{array}$ & $5.44 \pm 6.23 \mathrm{ng} / \mathrm{ml}$ & $\begin{array}{l}0.41 \pm 0.64 \\
\mathrm{ng} / \mathrm{ml}\end{array}$ & 0.01 & $89 \%$ & $85 \%$ & 0.929 & 0.69 & $\mathrm{~N} / \mathrm{A}$ & $\mathrm{N} / \mathrm{A}$ & $\mathrm{N} / \mathrm{A}$ & $\mathrm{N} / \mathrm{A}$ & N/A & $\mathrm{N} / \mathrm{A}$ & $\mathrm{N} / \mathrm{A}$ \\
\hline $\begin{array}{l}\text { Sachse } \\
\text { et al., } 1999\end{array}$ & $5.5 \mu \mathrm{g} / \mathrm{L}$ & $0.3 \mu \mathrm{g} / \mathrm{L}$ & 0.01 & N/A & $\mathrm{N} / \mathrm{A}$ & $\mathrm{N} / \mathrm{A}$ & 1.5 & $\mathrm{~N} / \mathrm{A}$ & $\mathrm{N} / \mathrm{A}$ & $\mathrm{N} / \mathrm{A}$ & $\mathrm{N} / \mathrm{A}$ & $\mathrm{N} / \mathrm{A}$ & $\mathrm{N} / \mathrm{A}$ & $\mathrm{N} / \mathrm{A}$ \\
\hline $\begin{array}{l}\text { Seoane } \\
\text { et al., } 2014\end{array}$ & $0.47 \mathrm{ng} / \mathrm{ml}$ & $0.61 \mathrm{ng} / \mathrm{ml}$ & 0.682 & N/A & $\mathrm{N} / \mathrm{A}$ & 0.546 & 1.7 & $\mathrm{~N} / \mathrm{A}$ & $\mathrm{N} / \mathrm{A}$ & $\mathrm{N} / \mathrm{A}$ & $\mathrm{N} / \mathrm{A}$ & $\mathrm{N} / \mathrm{A}$ & $\mathrm{N} / \mathrm{A}$ & $\mathrm{N} / \mathrm{A}$ \\
\hline $\begin{array}{l}\text { Von } \\
\text { Heimburg } \\
\text { et al., } 1998\end{array}$ & $49.8 \pm 76.9 \mathrm{ng} / \mathrm{ml}$ & $\begin{array}{l}2.3 \pm 3.7 \\
\mathrm{ng} / \mathrm{ml}\end{array}$ & $<0.005$ & N/A & $\mathrm{N} / \mathrm{A}$ & $\mathrm{N} / \mathrm{A}$ & 3.0 & $180 \pm 58 \mathrm{mg} / \mathrm{l}$ & $248 \pm 77 \mathrm{mg} / \mathrm{l}$ & $<0.005$ & $\mathrm{~N} / \mathrm{A}$ & $\mathrm{N} / \mathrm{A}$ & $\mathrm{N} / \mathrm{A}$ & $\mathrm{N} / \mathrm{A}$ \\
\hline $\begin{array}{l}\text { Wineberg } \\
\text { et al., } 2019\end{array}$ & $1.97(0.05-136.6)$ & $\begin{array}{l}1.18 \\
(0.05-165)\end{array}$ & 0.86 & $\mathrm{~N} / \mathrm{A}$ & $\mathrm{N} / \mathrm{A}$ & 0.658 & N/A & $\begin{array}{l}60(30-310) \\
\mathrm{mg} / \mathrm{l}\end{array}$ & $97(1-273)$ & 0.86 & N/A & N/A & 0.759 & $\mathrm{~N} / \mathrm{A}$ \\
\hline
\end{tabular}

In this systematic review, it showed that most of the previous studies proved that PCT levels were significantly different in burn patient group with sepsis compared to non-sepsis. Of the 11 studies evaluating the role of PCT as a diagnostic marker for sepsis in burn patients, nine studies [7], [17], [18], [19], [20], [21], [22], [23], [24] stated that PCT acted as a biomarker for predicting the sepsis incidence in burn patients. Only two studies, a study by Bargues et al. [8] and Seoane et al. [25], were not in line. Despite finding a significant difference between the mean PCT in the sepsis and non-sepsis groups, Bargues et al. [8] concluded that PCT was not superior to CRP and WBC. Meanwhile, Seoane et al. [25] found no significant difference in mean PCT between the sepsis and non-sepsis groups.

The cutoff values for PCT between the studies varied from 0.5 to $3 \mathrm{ng} / \mathrm{ml}$. The highest cutoff values were found in Heimburg's study [21] $(3 \mathrm{ng} / \mathrm{ml})$ and the lowest was found in Barati's study [17] $(0.5 \mathrm{ng} / \mathrm{ml})$. It was varied widely despite the use of the same immunoluminometric assay. The PCT sensitivity varied between $75.7 \%$ and $100 \%$ while the specificity was between $78.6 \%$ and $91.9 \%$. The main differences also appeared to lie in the number of sufferers and burn surface area. Burn surface area may have some potential correlation with PCT rates and the number of patients could affect the result reliability.

There were seven studies [7], [8], [17], [18], [19], [20], [21] measuring CRP in sepsis and non-sepsis groups. Five studies stated that the mean CRP in sepsis and non-sepsis groups differed significantly. Only studies by Barati et al. [17] and Wineberg et al. [24] found no significantly different results. Only Bargues [8] and Cakir [18] studies included CRP diagnostic test values. Bargues [8] found that the optimum cutoff value for CRP 
Study

ID

ES $(95 \% \mathrm{Cl})$

$\%$

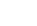

Barati et al., 2008

Bargues et al., 2007

Cakir-Madenci et al., 2014

Egea-Guerrero et al., 2015

Kim et al., 2012

Lavrentieva et al., 2012

Mokline et al., 2015

Overall (l-squared $=94.1 \%, p=0.000)$

Heterogeneity: $\mathrm{Chi}^{2}=102.48, \mathrm{df}=6(\mathrm{p}=0.000) ; \mathrm{I}^{2}=94.1 \%$; Test for overall effect: $Z=179.03(p=0.000)$

$-1$

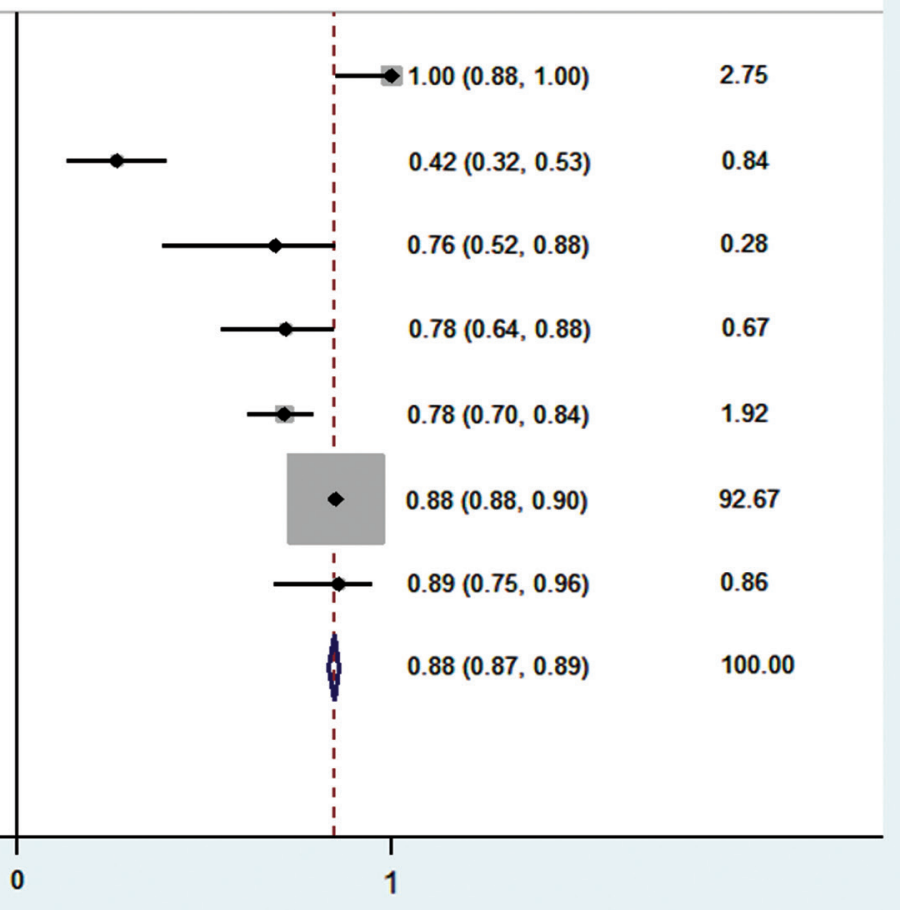

Figure 2: Forest plot of procalcitonin pooled sensitivity

Study

ID

ES $(95 \% \mathrm{Cl})$

ES $(95 \%$ Cl)

Weight

Barati et al., 2008

Bargues et al., 2007

Cakir-Madenci et al., 2014

Egea-Guerrero et al., 2015

Kim et al., 2012

Lavrentieva et al., 2012

Mokline et al., 2015

Overall $(1-$ squared $=0.0 \%, p=0.668)$

Heterogeneity: $\mathrm{Chi}^{2}=4.07, \mathrm{df}=6(\mathrm{p}=0.668) ; \mathrm{I}^{2}=0.0 \%$; Test for overall effect: $Z=66.06(p=0.000)$

$-.979$

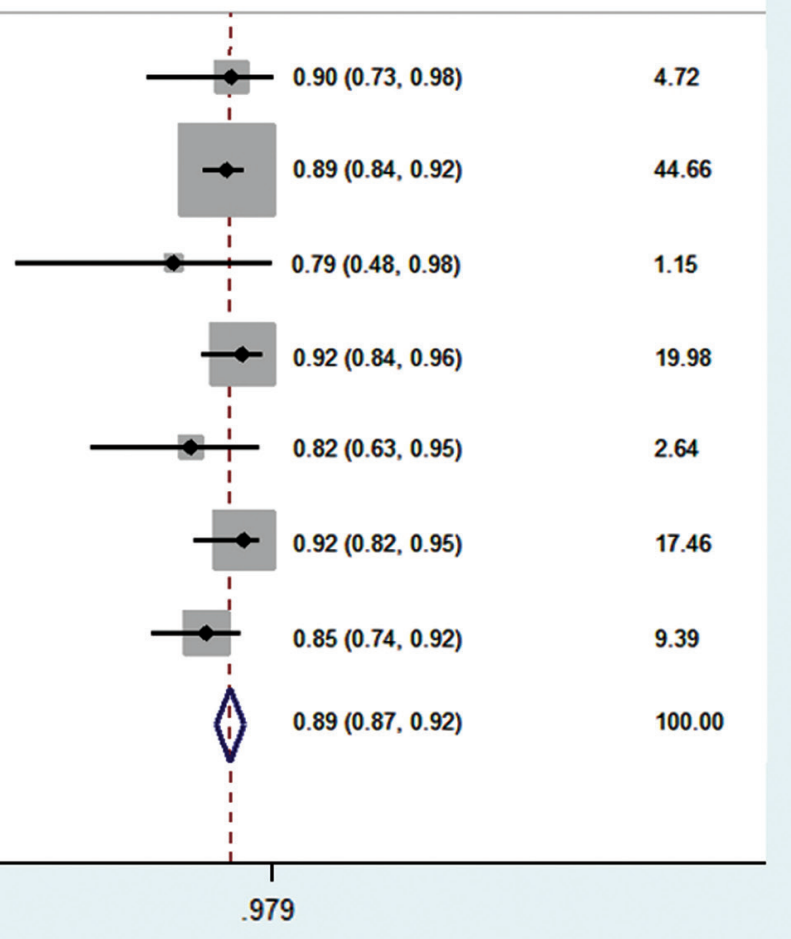

Figure 3: Forest plot of procalcitonin pooled specificity 


\begin{tabular}{|c|c|c|c|c|c|c|c|c|}
\hline Study & TP & FP & FN & TN & Sensitivity (95\% Cl) & Specificity (95\% Cl) & Sensitivity $(95 \% \mathrm{Cl})$ & Specificity (95\% Cl) \\
\hline Bargues 2007 & 73 & 106 & 19 & 161 & $0.79[0.70,0.87]$ & $0.60[0.54,0.66]$ & $\rightarrow$ & $\rightarrow$ \\
\hline Cakir-Madenci 2014 & 24 & 5 & 2 & 6 & $0.92[0.75,0.99]$ & $0.55[0.23,0.83]$ & & $\longrightarrow$ \\
\hline
\end{tabular}

Figure 4: Sensitivity and specificity of C-reactive protein

was $102 \mathrm{mg} / \mathrm{L}$ with sensitivity $79.5 \%$ and specificity $60.3 \%$. Cakir [25] stated a lower cutoff value of $65 \mathrm{mg} / \mathrm{L}$ with sensitivity of $91.6 \%$ and specificity of $58.2 \%$.

The combined sensitivity and specificity of PCT for this meta-analysis were $88 \%$ and $89 \%$, respectively. This finding was in line with the results of the meta-analysis conducted by Ren et al. showing that the specificity of PCT was higher than the sensitivity [26]. However, the individual studies show varied sensitivities (42.4-100\%) and specificities (78.6-95.2\%). The specificities seem much more stable than the sensitivities. This implies that PCT has a higher ability of differential sepsis from non-sepsis but is not sensitive in some situations. It was found that the stability of sensitivities increased when the patients' numbers rose [26].

The combined descriptive sensitivity and specificity of CRP from the two existing studies were $85.5 \%$ and $57.5 \%$, respectively. Although the difference in sensitivity between PCT and CRP was not very large, the difference in specificity was indeed large. A low CRP specificity showed many "false positives," so CRP would place many patients in sepsis group even though they were not sepsis.

The timing of biomarker being taken in each study was not same. Some studies perform a transient examination while others perform serial examinations. The levels of these biomarkers definitely would be different when taken at the time of initial onset of sepsis or when septic shock has occurred. Biomarkers may peak later after clinical changes have occurred. Serial tests to see the tendency for changes in these biomarkers will probably be more meaningful.

Despite the existed guidelines to define sepsis and concept of SIRS, they have been criticized for their oversensitivity and nonspecific. This has led ABA to produce specific consensus guidelines about definition of infection and sepsis in burn patients. However, there is still no ideal definition of sepsis with high sensitivity and specificity for burn patients so that the main problem in the field is the lack of uniformity in understanding sepsis and the difficulty of diagnosing sepsis [26]. The establishment of sepsis in this systematic review used criteria defined by the American College of Chest Physicians and Society of Critical Care Medicine Consensus about Definitions of Sepsis, ABA, and based on clinical conditions. It was being a weakness for this study because the index test used was not uniform across studies.

It should be noted that in this study that we only included 11 studies. For analyzing PCT diagnostic test value, only seven studies were included. Meanwhile, a similar assessment could not be made for CRP because there were only two related studies. Not all studies had demonstrated the sensitivity and specificity of PCT and CRP. Comparison of pooled sensitivity and specificity of PCT and CRP could only be done descriptively and not statistically. There was potential publication bias in the enrolled studies since positive results were more likely to be published than negative results, which affected the pooled diagnostic validity. This study only included published studies in English so there was a possibility missing important data that might be stated in other valued studies published in other languages.

PCT or CRP may not be the most ideal marker for the initial diagnosis of sepsis in burn patients. A truly ideal biomarker may not exist because sepsis is a complex pathophysiological process difficult to be explained by a single biomarker [26]. The sensitivity and specificity of each biomarker in diagnosing sepsis are still insufficient for its application as a single modality for early sepsis diagnosis in major burn patients. To increase the sensitivity and specificity, a combination with other biomarkers, clinical signs, and microbial culture is required. This is an interesting topic to discuss in future studies.

Although the results of this study indicated that PCT had a better diagnostic test value than CRP, its use in deciding patient's therapy must be applied wisely and correlated with clinical and other investigations. Further studies with large-scale and multicentered cohort prospective are needed to minimize the bias. Studies in extreme age and comorbidity population are also needed.

\section{Conclusion}

Based on systematic review, it was found that PCT had a better diagnostic test value rather than CRP for diagnosing sepsis in adult major burn patients (sensitivity $88 \%$ vs. $85.5 \%$; specificity $89 \%$ vs. $57.5 \%$ ). Thus, CRP tends to show more falsepositive results. However, PCT should be examined wisely and should not be considered as the sole determinant to diagnose sepsis in patients with major burns. This biomarker examination must be correlated with clinical and other supporting conditions. The serial examinations may have a better meaning rather than occasional one. 


\section{References}

1. Greenhalgh DG. Sepsis in the burn patient: A different problem than sepsis in the general population. Burns Trauma. 2017;5:23. https://doi.org/10.1186/s41038-017-0089-5 PMid:28795054

2. John J, Chisthi MM, Kuttanchettiyar KG. C-reactive protein: An early predictor of sepsis in patients with thermal burns. Int Surg J. 2017;4(2):628-32. https://doi.org/10.18203/2349-2902. isj20170204

3. Yan JY, Hill WH, Rehou S, Pinto R, Shahrokhi S, Jeschke MG Sepsis criteria versus clinical diagnosis of sepsis in burn patients: A validation of current sepsis scores. Surgery. 2018;164(6):1241-5. https://doi.org/10.1016/j.surg.2018.05.053 PMid:30049483

4. Bloss F, Reinhart K. Rapid diagnosis of sepsis. Virulence. 2014;5(1):154-60.

PMid:24335467

5. Cabral L, Afreixo V, Almeida L, Paiva JA. The use of procalcitonin (PCT) for diagnosis of sepsis in burn patients: A meta-analysis. PLoS One. 2016;11(12):e0168475. https://doi.org/10.1371/ journal.pone. 0168475 PMid:28005932

6. Yichao X, Jin X, Shao X, Zheng F, Zhou H. Valuable prognostic indicators for severe burn sepsis with inhalation lesion: Age, platelet count, and procalcitonin. Burns and Trauma. 2018;6:29. https://doi.org/10.1186/s41038-018-0132-1

PMid:30397617

7. Lavrentieva A, Papadopoulou S, Kioumis J, Kaimakamis E, Bitzani M. PCT as a diagnostic and prognostic tool in burn patients. Whether time course has a role in monitoring sepsis treatment. Burns. 2012;38(3):356-63. https://doi.org/10.1016/j. burns.2011.08.021

PMid:22037153

8. Bargues L, Chancerelle $\mathrm{Y}$, Catineau J, Jault P, Carsin H Evaluation of serum procalcitonin concentration in the ICU following severe burn. Burns. 2007;33(7):860-4. https://doi. org/10.1016/j.burns.2006.10.401

PMid: 17532575

9. Chivate CG, Belwalkar, Limaye RP, Patil RV. Procalcitonin as a marker for the diagnosis of sepsis. Int $\mathrm{J}$ Res Med Sci. 2016;4(4):1216-8. ijrms20160812 https://doi.org/10.18203/2320-6012.

10. Patel DD, Rosenberg M, Rosenberg L, Foncerrada G, Andersen CR, Capek KD, et al. Poverty, population density, and the epidemiology of burns in young children from Mexico treated at a U.S. pediatric burn facility. Burn. 2018;44(5):126978. https://doi.org/10.1016/j.burns.2018.02.003 PMid:29551448

11. The Joanna Briggs Institute. Joanna Briggs Institute Reviewers Manual 2015: The Systematic Review of Studies of Diagnostic Test Accuracy. Australia: The Joanna Briggs Institute; 2015. https://doi.org/10.1111/j.1365-2648.2009.05065.x

12. The Joanna Briggs Institute. Critical Appraisal Checklist for Diagnostic Test Accuracy Studies. Australia: The Joanna Briggs Institute; 2017.

13. Mann EA, Wood GL, Wade CE. Use of procalcitonin for the detection of sepsis in the critically ill burn patient: A systematic review of the literature. Burns. 2011;37(4):549-58. https://doi. org/10.1016/j.burns.2010.04.013 PMid:20537467

14. Pileri D, Accardo-Palumbo A, D'Amelio L, D'Arpa N, Arnone G, Grisaffi C, et al. Serum levels of cortisol, immunoglobulin, and C-reactive protein in burn patients. Ann Burns Fire Disasters.

\section{9;22(1):3-5.}

PMid:21991143

15. Wu CC, Lan HM, Han ST, Chaou CH, Yeh CF, Liu SH, et al. Comparison of diagnostic accuracy in sepsis between presepsin, procalcitonin, and C-reactive protein: A systematic review and meta-analysis. Ann Intensive Care. 2917;7(1):91. https://doi.org/10.1186/s13613-017-0316-z PMid:28875483

16. Li H, Yao Z, Tan J, Zhou J, Li Y, Wu J, et al. Epidemiology and outcome analysis of 6325 burn patients: A five-year retrospective study in a major burn Center in Southwest China. Sci Rep. 2017;7:46066. https://doi.org/10.1038/srep46066 PMid:28383066

17. Barati M, Alinejad F, Bahar MA, Tabrisi MS, Shamshiri AR, Bodouhi NO, et al. Comparison of WBC, ESR, CRP and PCT serum levels in septic and non-septic burn cases. Burns. 2008;34(6):770-4. https://doi.org/10.1016/j.burns.2008.01.014

PMid: 18513877

18. Madenci ÖC, Yakupoğlu S, Benzonana N, Yücel N, Akbaba D, Kaptanağası AO. Evaluation of soluble CD14 subtype (presepsin) in burn sepsis. Burns. 2014;40(4):664-9. https://doi. org/10.1016/j.burns.2013.08.024

PMid:24074718

19. Egea-Guerrero JJ, Martínez-Fernández C, RodríguezRodríguez A, Bohórquez-López A, Vilches-Arenas A, PachecoSánchez $M$, et al. The utility of C-reactive protein and procalcitonin for sepsis diagnosis in critically burned patients: A preliminary study. Plast Surg (Oakv). 2015;23(4):239-43. https://doi.org/10.1177/229255031502300412

PMid:26665138

20. Sachse C, Machens HG, Felmerer G, Berger A, Henkel E. Procalcitonin as a marker for the early diagnosis of severe infection after thermal injury. J Burn Care Rehabil. 1999;20(5):354-60. https://doi.org/10.1097/00004630-199909000-00004

PMid: 10501320

21. von Heimburg D, Stieghorst W, Khorram-Sefat R, Pallua N. Procalcitonin-a sepsis parameter in severe burn injuries. Burns. 1998;24(8):745-50. https://doi.org/10.1016/ s0305-4179(98)00109-0

PMid:9915676

22. Kim HS, Yang HT, Hur J, Chun W, Ju YS, Shin SH, Kang HJ, Lee KM. Procalcitonin levels within 48 hours after burn injury as a prognostic factor. Ann Clin Lab Sci. 2012;42(1):57-64.

\section{PMid:22371911}

23. Mokline A, Garsallah L, Rahmani I, Jerbi K, Oueslati H, Tlaili S, Hammouda R, et al. Procalcitonin: A diagnostic and prognostic biomarker of sepsis in burned patients. Ann Burns Fire Disasters. 2015;28(2):116-20

\section{PMid:27252609}

24. Wineberg D, Moore R, Kruger D. Procalcitonin and bacteria sepsis in burn patients in South Africa. J Surg Res. 2020;246:4908. https://doi.org/10.1016/j.jss.2019.09.040 PMid:31635838

25. Seoane L, Pértega S, Galeiras R, Astola I, Bouza T. Procalcitonin in the burn unit and the diagnosis of infection. Burns. 2014;40(2):223-9. https://doi.org/10.1016/j.burns.2013.11.018 PMid:24439927

26. Ren H, Li Y, Han C, Hu H. Serum procalcitonin as a diagnostic biomarker for sepsis in burned patients: A meta-analysis. Burns. 2015;41(3):502-9. https://doi.org/10.1016/j.burns.2014.08.019 PMid:25648378 